\title{
9. Transnationalism of Merchant Seafarers and their Communities in Kiribati and Tuvalu
}

\author{
Maria Borovnik
}

\section{Introduction}

Seafarers cannot be immediately recognised as contributing to the transnationalism of their home countries. Criss-crossing internationalised, de-nationalised and national waters during their employment on merchant vessels and living with multi-national crews, seafarers could rather be seen in many ways as pioneers of global citizenship. ${ }^{1}$ Despite the dynamic of their employment and the transversal and circulating movement between home and shipboard communities, seafarers from Kiribati and Tuvalu still maintain strong links to their families and cultures at home. These family and cultural connections include regular remittances, money sent back home, but also in exchange the reception of culturally meaningful material from families, and the maintenance of activities and memories while working on ships, connects seafarers to their homes. This chapter adopts a framework that considers transnationalism as a dynamic, multi-dimensional and multi-inhabited space.

Recruitment of Pacific seafarers working for international merchant vessels had for a long time a rather informal touch. The British owned China Navigation company (now Swires, UK, based in Hong Kong), for example, recruited men from the Gilbert and Ellice Island colony since 1959 (Connell 1983, 33), originally for their transport ships between Nauru, Tarawa and Funafuti, and then by manning their international merchant ships with men from the same region. This informal and on-the-job trained recruitment changed, however, significantly in 1966 when the German Hamburg Süd Dampfschiffahrtsgesellschaft (HSDG or Hamburg Süd) discovered employment opportunities on the shores of Tarawa (Sieg 1999).

The discovery of recruiting opportunities in the central Pacific was followed by the construction of marine training facilities on Betio, Tarawa (Marine Training Centre or MTC), ${ }^{2}$ and after a number of successful deployments onboard German and British vessels, the HSDG decided to establish a recruitment agency in 1969, consisting of a conglomeration of German and British shipping companies, that would make the international employment of young I-Kiribati ${ }^{3}$ and Tuvaluan men possible. It was only about ten years after the establishment of SPMS that first Tuvalu in 1978 and then Kiribati in 1979 became independent from the 
former British Protectorate. Already in early years, the British based shipping company had left SPMS, and the agency consisted from then on of German shipping companies only. ${ }^{4}$ SPMS facilitated signing up of men to their vessels under exceptional national German agreements. ${ }^{5}$

After independence, Tuvalu opened its own marine school, which is now the Tuvalu Maritime Training Institute (TMTI) on Amatuki Island of Funafuti atoll; and a Funafuti based recruitment office, which is now the Tuvalu Marine Service (TMS). Only a few years later, independently from SPMS/TMS, a German company decided to recruit Tuvaluans only through the Alpha Pacific Navigation Limited (APNL) agency. Kiribati's options for employment of seafarers also extended, when a conglomerate of Japanese tuna companies decided in 1989 to invest in training and recruitment of men on fishing vessels. Since 2002 employment on Norwegian cruise liners has become possible for men and, since 2003, for women working aboard in catering services. The SPMS has recently taken a leap of faith when under relatively strict pre-conditions and safety measures, the first I-Kiribati women seafarers have been trained in 2005 as cooks and stewards and recruited onboard merchant vessels.

The development in training and recruitment facilities in Kiribati and Tuvalu, can be seen as a reflection of the entry of the shipping industry into globalisation in the late 1960s and beginning 1970s. These early initiations were followed by a rapid development of merchant shipping as a multinational and international industry, characterised by a progression into 'internationalising' crews, management and ship nationality. It is true today that merchant multinational crews are under multinational management, registered under special 'de-nationalised' ${ }^{6}$ agreements on ships with international flags, traversing through international and de-national maritime space (Borovnik 2004, Lane 1999; Sampson 2003). It can be argued that within this complex and highly competitive global system it is the maintenance of strong cultural identities and values, together with the acceptance of mobility as a means of network activities of family or community members, and the responsibility of sending remittances to their home countries, that have led to the successful and ongoing participation of I-Kiribati and Tuvaluan seafarers for almost forty years.

The recruitment history, however, also reflects on the division of the two world-systems that Germany and Kiribati/Tuvalu symbolise, and also the economic aspects of such relationships that accompanied the globalisation process of the shipping industry. There were, and still are, significant levels of unemployment and low economic resources in Kiribati and Tuvalu, which made it possible for old and well established European companies to offer employment contracts that would be attractive for Tuvalu and Kiribati and lucrative for their own management. In doing so, managers of HSDG emphasised both their economic interest and their concern in helping to develop small countries in the 
Pacific. Hence, the establishment of marine training facilities first on Tarawa, and then later on Funafuti ensured a high standard of employment for I-Kiribati and Tuvaluan seafarers. The provision of good training, nowadays based on international Standards of Training Certification and Watchkeeping (STCW), has resulted from what Lane $(1999,24)$ describes as 'values of pride in craft'. Long established shipping companies desired links between strong nation based values of employment standards with 'mundane rituals and symbols' of 'organically linked' shipboard societies, and hence sustained 'an occupational culture' even though members of these societies had become multinational (Lane 1999, 23f). This aspect of 'pride in craft' can still be found in the attitudes of some of the older or retired I-Kiribati and Tuvaluan seafarers today, especially those that are now working onshore, in marine training institutions, or for recruitment agencies. ${ }^{7}$

As a result of deregulation processes and structural changes in the shipping industry, 'there are at any one time approximately one million seafarers aboard ships, operating in international ports and waters, who live and work in communities which are multinational and which exist beyond national boundaries' (Sampson 2003, 260, emphasis in original). Elsewhere I have discussed the combination of sharing a work environment that involves travelling through waters of different national or de-national regulations, and in such a confined space as a vessel, as a reality on the 'edges' of transnationality (Borovnik, 2003, 2004; and see Sampson, 2003; Yeoh et al, 2003). The long established rituals and links between shipboard communities, employers and merchant seafarers create transnational communities in a wider sense, when we adopt a framework that includes dynamic circulating spaces and when we include the regular maintenance of strong links and activities between international seafarers and their home countries.

This paper is based mainly on extended information gathered on Kiribati through six months fieldwork in 1999, where a total of 136 individual interviews and six focus groups were conducted on Tarawa and two outer islands with seafarers, their wives, parents and family members, village elders, both men and women, government officials, managers and employees of recruitment agencies, union leaders, women's groups, church leaders, medical personnel, and others. Some of these interviews were interpreted by local field assistants. Some of this qualitative information, and remittances data, was then updated by two subsequent short visits to Kiribati in 2004 and 2006, and a few days in Tuvalu in 2006.

I will, in the following section, provide brief background information on Kiribati and Tuvalu and then place this chapter into the framework of transnationalism, by linking it with seafarers and with mobility in the Pacific. Transnational frameworks discuss the nation state as significant, but in the context of Pacific 
seafarers a more dynamic concept must become the key unit of analysis, linking directly to the concept of family. This argument will then be illustrated by relating it to seafarers from Kiribati.

\section{Kiribati and Tuvalu}

Kiribati and Tuvalu, both low lying atoll island states, have relatively small land surfaces with 810.5 square $\mathrm{km}$ for Kiribati and 24.4 square $\mathrm{km}$ for Tuvalu. Due to their Exclusive Economic Zones they have vast maritime space, 3.5 million square $\mathrm{km}$ for Kiribati and 750,000 square km for Tuvalu (Asian Development Bank 2002a, 2002b; Connell 2003, 92). Population sizes are small: an estimated 97,000 for Kiribati, and just 10,000 people in Tuvalu. Problematic, however, is the high percentage of young population ${ }^{8}$ and rapid urban growth ${ }^{9}$ which leads to density and environmental problems in both capital islands, Tarawa and Funafuti. As small island economies these countries face challenges such as small market size, distance from markets or main centres, higher transportation costs, and because of their remote location, both sea freight charges and costs to passengers are high.

Distances and high transport costs are a disadvantage for island economies, as it makes tourism difficult and circular labour migration costly (World Bank 2006). Both countries' economic growth is concentrated on their public sectors (Asian Development Bank 2002a,b) with consequentially small private sectors; the Tuvalu private sector contributes approximately 30 per cent to GDP, with only 15 per cent business participation (Conway 2006); private sector employment in Kiribati accounts for 25 per cent in total (Asian Development Bank 2002a). Added to the economic challenges are environmental challenges, such as low rainfall, lack of natural resources, the occurrence of cyclones in Tuvalu, and the threat of sea level rise.

Existing migration schemes for Kiribati and Tuvalu are small. In contrast to many other Pacific nations, Kiribati and Tuvalu do not have the privilege of free access to one of the Pacific Rim countries. Under the Pacific Access Quota, however, both countries are granted entry for 75 people each to New Zealand. This access has a number of strict conditions, such as applicants having to hold a job offer at the time of application (New Zealand Immigration 2007). Since 2006 New Zealand has offered a 'seasonal working scheme', allowing some Pacific Islands, including Tuvalu and Kiribati to apply for contract work in vineyards and orchards.

In view of the relatively vulnerable economic circumstances and the restriction of free movement, it can be said that the seafarer scheme has turned out to be very successful for both countries, making a significant contribution to the Kiribati and Tuvaluan economies. Remittances make an estimated contribution of 15 to 20 per cent to Kiribati's and 50 per cent to Tuvaluan's national income. 
Kiribati currently receives remittances of AUD\$12-13 million dollars (Borovnik 2006); Tuvalu AUD\$3-4 million (Boland and Dollery 2005).

\section{Placing Seafarers in the Concept of Transnationalism}

Considering the dynamics of current international types of contract labour migration it is the recognition of multiple and constant interconnections and networks across international borders that has made the framework of transnationalism popular and suitable for the inclusion of labour circulation and movements that are more than just uni or bi-directional (Glick Schiller, Basch, Szanton Blanc 1995; Pries 1998,). These include the shift from the consideration that contract labour across national borders would have only been sought out in order to achieve economic advancement (Portes 1997), to the inclusion of social and cultural aspects, for example that migrants as well as circulating contract workers lead dual lives with regular contact between migrant and home community (Portes Guarnizo, Landoldt 1999). The new concept also includes multiple circular movements that can lead to frequent and strong links between countries, common identities, and to the development of transnational spaces, mobile livelihoods and transnational communities (Duany 2002; Portes 2003; Vertovec 2001, 2003; Wimmer and Glick Schiller 2003). Of particular interest for the circumstances of seafarers is the aspect of negotiation of common identities that had been recognised by Vertovec (2001), and that social practices between migrants and their communities at home could be regarded as articulations of transnationality (Lee 2007; Levitt, DeWind and Vertovec 2003).

These notions on transnational space and mobility have led to geographical space becoming an increasingly fluid concept. Crang, Dwyer and Jackson (2003:445) argue that it is not the boundaries of the nation states but the processes that matter: 'the nation state continues to play a key role in defining the terms in which transnational processes are played out'. These authors, however, feel that transnational space should also include 'fluid maritime space' and this could be expressed by Leontis' (1997:181) concept of emporion, which is based on an old Greek meaning of circulations of 'traffic in merchandise, especially by ship'. Other authors, for example Gilroy (1993), Young (1998), and Steinberg (1999) have in different geographical contexts also referred to movements, especially by ship, and involving international communities, as connecting and continuing relationships, including social-cultural and economic ones, that have been made in the different spaces of home, across and abroad (Borovnik 2005:136).

Expanding on such discussion, Crang, Dwyer and Jackson (2004) continue by emphasising processes and connecting spaces, by defining transnationalism as a dynamic, complex, multi-dimensional and multi-inhabited encompassing field. It is because of this definition that we can now conclude that international seafarers and their families are no longer on the 'edges' of transnationalism, but are fully fledged members of transnational practice. It may be easily recognised 
that seafarers are encompassed in a field that occupies a dynamic and complex mobile livelihood onboard ship, under agreements and regulations of different national context, needed in order to make international employment possible. This dynamic space is multi-dimensional both in a geographic and socio-cultural sense; and it is multi-inhabited by the varying nationalities of ship-owners, managers, officers and multinational crews, and the fact that ships are registered under so called 'foreign' or international flags.

\section{Movements and Networks of Pacific People}

Social and organisationally informal networks in combination with transnational movements and the exchange of practices and information have been increasingly recognised as highly functional. These networks are also regarded as contributing effectively to development because of the aspects of fluidity and reciprocity that are involved (Bebbington 2002; Gibson-Graham 2005; Henry, Mohan and Yancopulos 2004). In this theoretical context, two recent publications have acknowledged and referred to the long history of cultural and family connections and networking over time and space in context of migration and mobility in the Pacific. The first one, a working paper by Barcham, Scheyvens and Overton (2007) suggests a 'New Polynesian Triangle', extending from historical Polynesia, and relatively restricted movements during colonial times, to an extended and more complex Polynesia that participates and is affected by the dynamics and neoliberal politics of globalisation and has perhaps, despite such politics, extended to include places and transnational communities in Australia, New Zealand and the USA.

Movements within such a new Polynesian transnational space must include the multi-dimensional nature of migration and the ties that bind people to their homeland, resulting in movements of people and their expressions of identity that are multidirectional (Barcham, Scheyvens and Overton 2007). The authors refer in particular to Polynesian families living in nations with strong political links to the Pacific Rim, including Samoa, Tonga, Cook Islands, Niue and Hawai'i. They refer to the expanding concepts of transnationalism but emphasise the important aspect of culture and family as key unit of analysis, and advocate a clearer understanding of the complexities of transnational flows, such as remittances, that can be both multi-directional and embrace symbolic and cultural meanings, which may be seen as equally significant to economic importance (see also Borovnik 2005; Koteka-Wright 2006; Marsters, Lewis and Friesen 2006 in this context).

Basing their arguments on Hau' ofa (1993:6), Barcham, Scheyvens and Overton (2007:8) explain that in an increasingly unfavourable geo-political climate, Polynesians have moved even further afield - yet this expansion of movement has, for too long, been disregarded', and people expand their movements by crisscrossing the boundless ocean as always. These arguments are based on the 
frequent flows between Oceania and the Pacific Rim, and reject discourses on migration that only focus on aspects of permanence and assimilation in new places, by showing that in the context of Polynesians we cannot conclude as such. Although this paper did not include Micronesia, it can clearly be linked to the transnational practices and experiences of seafarers in the Pacific, and hence, these arguments can be regarded as suitable for Tuvaluan as well as I-Kiribati families.

The second publication concerned with 'The Pacific Islanders and the Rim: Linked by Migration' is a special issue in the Asia Pacific Migration Journal edited by Carmen Voigt-Graf (2007a) which addresses the larger region of Oceania. Again, the 'extraordinarily large migration flows' in the region are being observed (Voigt-Graf 2007b, 143), and the large Polynesian component at least in New Zealand and Australia has been recognised. This issue also addresses the MIRAB debate and strong views on remittance dependence in 1995 (Brown and Connell 1995). The contributors expand on these debates by including aspects on social networks, identities and cultural changes in more detail, addressing shifts in migration discourses including now second generations and a more positive view on remittances. This issue, however, also addresses the multiple directions and symbolic of transnational flows and the need for more research on the social aspects of the affects of migration and labour circulation (see Connell 2007; Lee 2007).

In conclusion, discourses on transnationalism, especially in the context of Pacific seafarers have now included different scales of geographies as well as social, cultural and economic components of networks resulting from the multiplicity of movement articulations especially within the Pacific context under the influence of globalisation.

\section{Seafarers and their Homeland: Examples from Kiribati}

The previous discussions make it possible to argue that there are certain occupational aspects linked to networking, multidirectional flows and exchange that can be observed in the I-Kiribati seafaring experiences. Firstly, the long absence from home, which has in the last couple of decades been up to two years at a time, interspersed with often short time periods at home, from a few weeks to several months. Strong cultural connections to Kiribati are, secondly, responsible for networking across dynamic space and over long space and time distances. These include the preservation of cultural knowledge, practices, and remittances flows as part of seafarers' family and community obligations. Lastly, the exchange of old and new experiences combined with the 'adventure' of moving between and observing unfamiliar places, the strict working conditions, and the new multicultural experiences onboard, that merge with old values and the homeland experiences of seafarers. ${ }^{10}$ 
In order to place such aspects within content, I will look at some different examples. Seafarers usually experience a mixture of fear and excitement at going onboard merchant vessels for the first time, especially when they are single and this is their first time away from home. The excitement may then wear off, and feelings of longing for their homelands become prevalent. These feelings may deepen as men begin to cope with the monotony of work on vessels and the confined spaces that allow them little personal distance from their colleagues. ${ }^{11}$ One 34 year old man had been working for a period of 16 years for SPMS at the time of interview. His first trip was on a general cargo vessel for a period of two years which he started when he was 18 years old. He talks about the excitement of this first experience in 1983: 'I thought it was [as though] I started an adventure. ... I was still single. I met my wife in 1988 and we got married in 1992'. He then goes on to explain how he boarded his first ship in Durban, a place he had never been to before, where it was freezing cold from his point of view, and how he journeyed from there to Brazil. The following quote expresses his feelings:

It was a new country and so a new thing for me. That's what it [was] like when I was stepping on [land in Brazil]. When I first got off the ship and I was walking around down there, I thought, it's a different world! I have never been in this part of world before ... When I first went out I wasn't actually very homesick, because the ship kept on going to different places all the time. And you sort, you know, it's a good place, you can see, you know, you look forward to see new places. And then, on the second ship, yeah, I sort of started feeling lonely and started feeling very homesick.

$M B$ : Why was that?

Well, you get to spend a lot of time on the ship and you are there about six months already and you are thinking, ah, I've been here too long really, you know, it's time to go home. And you miss your friends, and your lifestyle and what you were used to do at home. Like me, if I would get work in Kiribati, there is no way I would like to stay in another country. I'd come back to my country again.

$M B$ : Why is that?

I just love my country $<$ laughter $>$

When I asked more specifically, what exactly he loved so much about 'his' country, this seaman explains that the main reason was 'the family', and then generalising his experience with other I-Kiribati, who also always will return home for this same reason, says, 'you know [Kiribati is] very easy especially for living and all that kind of thing; especially, the activities that we are doing all the time; we can't do that on the ship'. This example shows the close relationships 
that the I-Kiribati seamen keep with their home country as a place they belong to because their family lives there and because this is the place of their upbringing, where family land is based and also where they know how to get around.

Remittances as a means for networking and keeping in contact have been discussed in detail among scholars working in the Pacific (for example by Connell and Conway 2000; Koteka-Wright 2006; Lee 2007; Marsters, Lewis and Friesen 2006). A more detailed discussion on remittances flows between seafarers and their families can be found in Borovnik (2006). A key point of this chapter is that as previously mentioned, overall remittances sent back to Kiribati (and Tuvalu) have increased. Remittances are often sent both to individual family members and to seafarers' personal bank accounts. In some cases seafarers have arranged joint bank accounts with their wives. Remittances from seafarers are of particular interest because they are usually arranged upon boarding vessels, and these arrangements guarantee, usually, a relatively steady flow of income for dependents, interrupted only when a seafarer is in between contracts. In the Kiribati context, however, it has been demonstrated that not only is there a direct benefit for individual families from remittances, but that remittances will reach a larger group of extended family members through firstly, the system of bubuti, or non-refusable request, that allows extended family members to request money, goods or favours when in need; and secondly through family and community obligations, such as providing school fees for nieces and nephews and sending money directly to churches or communities; and thirdly through obligations that family members receiving remittances have to follow up (Borovnik 2006).

This system is well illustrated by the following example: at the time of this interview the interviewee was a retired seafarer of unknown age. He had participated, as he explains, in one of the first intakes into MTC in the 1960s, although he had stopped working in 1986 as he needed to come home to support his mother who had become very ill at that time. This man now lives with his wife and extended family on one of the outer islands of Kiribati, and remembers that he used to send back fifty (Australian) dollars to his wife and thirty dollars to his parents in his early years of deployment. Then after a while, he sent more money. He explains:

[When I was on] my seventh ship I sent to my wife only fifty, yeah, fifty; and to my parents fifty also. Ah, and [on] my tenth ship it is more. I sent more money; to my wife one hundred, and to my father one hundred also. Two hundred I sent. I sent all the rest of my money to my bank. Save it. I have [keep] twenty dollars, yeah? I sent all my [other] money to my bank. But [sometimes] I have fifty dollars, and the rest I send to the bank. 
The money he kept monthly while working on board could vary from twenty to fifty dollars, and this was spent on drinks, clothes and smaller items needed. The amount of money this man had sent to his own bank account lasted him and his family for five years after he retired. However, while still employed, his family enjoyed the use of a stereo, a motorcycle, a radio, a kerosene stove and a suitcase. ${ }^{12}$ He also used to bring back perfumes, necklaces and a ring for his wife. His earnings allowed him to regularly contribute to the Catholic Church, sometimes three hundred dollars, sometimes one hundred, depending on what he decided at each time. After his mother died, he would have liked to go back to work, but his wife wanted him to stay at home, so he did. Instead he helps out now with some casual jobs in his own community.

In order to make time on board more bearable some family members and wives send items to their men, such as pillow cases, Te Uekerae, the local newspaper, video tapes filmed by a local company with traditional I-Kiribati features, photos and even audio tapes with greetings. A 37 year old woman married to a seafarer, working as cook, explains:

Because he said that he is lonely every day, every night, when he finishes work and he always drinks and what? Watches the video after work, then he sleeps to six o'clock in the morning, or five, to wake up and prepare all the breakfast for, them, the crews and the officers. That's what he said to me. ... Then, I make the pillow cases [with labels that say] 'Don't forget to say a prayer before you wake up'. Hm! And then 'Merry Christmas and Happy New Year', because Christmas is his birthday. So, [I put] one in the pack like this. I send it to the ship and his fish and the parcel is full to the top! Hm! You know what? With a birthday card, the lavalava, ${ }^{13}$ that I make it with cotton. The pillow cases... < then whispers $>$ He's a nice guy. Do you want to see his photo?

With the help of these few illustrations it is possible to explain some of the characteristics of exchange and regularity that accompany the very particular circumstances that seafarers and their families have to abide with. The combination of a strong sense of family and cultural connections and obligations with activities that help following up such connectedness have established a well working multi-directional and multi-dimensional network of transnationality between seafarers and their families. Aspects that explore newly learned ship-board community values and understandings have not been included in this chapter, although these form part of the articulations of seafarers' transnationalism. What we can see, with help of the above illustrations, is that through direct flows between individuals the wider extended family networks and community are also included. Even the conservation of seafarers' identity with their home countries are a consequence of such flows. 


\section{Conclusions}

It is not the boundaries of the nation-state but the processes, symbols and meanings within it that are the defining terms in which transnational processes are played out. Indeed that theme was one of the key arguments made by Crang, Dwyer and Jackson (2003:445) in combination with Barcham, Scheyvens, and Overton (2007). The illustrations chosen for this chapter help to confirm these defining elements. The strong connections between family members and the high standard of personal obligation to cultural practices draw I-Kiribati seafarers to live in or to return to their home country. It is these complex networks of communication and remittance flows that enable and sustain interactions between shipboard and home communities and even though initiated by individuals that ultimately connect seafarers with their home countries.

This chapter has discussed the importance of shifting away from strictly confined geographical space and national borders to a new concept of transnationalism embracing liminal space that includes different dimensions, such as the maritime and mobile space of shipboard communities, and focuses on families and communities as key units of analysis. Nation states remain still significant in terms of a mutual idea of homeland, as the example of Kiribati could show, but the emphasis lies on connections to families and places, and the complexities and multi-dimensions of how these connections are lived. A new concept of analysis also must still include the geographical and political history of Oceania, and the history of employer/employee relationships that are increasingly affected by global forces. This concept will then include clearly the history of Kiribati and Tuvalu that have been linked by seafaring for half a century. The shipping industry, both serving as an end and as a means for transport of goods and people, is truly a global force. We may conclude that processes within the Tuvaluan and I-Kiribati culture, and a long history of family obligations have built the well functioning networks between seafarers and their home countries that have led to increasing opportunities to participate in such a global system, yet retain the crucial values of home and keep these intact over time.

\section{References}

Asian Development Bank. 2002a. Kiribati. Monetization in an atoll society. Managing economic and social change. Asian Development Bank report in consultation with the Government of Kiribati and with support from AusAID.

- . 2002b. Tuvalu. 2002 Economic and public sector review. Asian Development Bank report in consultation with the Government of Tuvalu and with support from AusAID.

Barcham, M., R. Scheyvens, and J. Overton. 2007. Rethinking Polynesian mobility: A new Polynesian triangle? Centre for Indigenous Development 
Working Paper Series No.3

http://cigad.massey.ac.nz/documents/wps_Barcham\%20et\%20al\%20wp\%203_2007.pdf (accessed 28 April 2008).

Bebbington, A. 2002. Global networks and local developments: Agendas for development geography. Tijdschrift voor Economische en Sociale Geografie 94 (3): 297-309.

Boland, S. and B. Dollery. 2005. The economic significance of migration and remittances in Tuvalu. Working Paper Series in Economics number 2005-10, University of New England, School of Economics.

Borovnik, M. 2007. Labor circulation and changes among seafarers' families and communities in Kiribati. Asian and Pacific Migration Journal 16 (2): 225-50.

—. 2006 Working overseas: Seafarers' remittances and their distribution in Kiribati. Asia Pacific Viewpoint 47 (1): 151-61.

-. 2005. Seafarers" "maritime culture" and the "I-Kiribati way of life": The formation of flexible identities. Singapore Journal of Tropical Geography 26 (2): 132-50.

- 2004 Are seafarers migrants? Situating seafarers in the framework of mobility and transnationalism. New Zealand Geographer 60 (1): 14-21.

- 2003. Seafarers in Kiribati. Consequences of International Labour Circulation. PhD diss., University of Canterbury, Christchurch.

Brown, R. and J. Connell (eds). 1995. Special Issue on 'Migration and Remittances in the South Pacific'. Asia Pacific Migration Journal 4 (1).

Connell, J. 1983. Migration, employment and development in the South Pacific: Kiribati. Noumea, New Caledonia: ILO.

- 2003. Losing ground? Tuvalu, the greenhouse effect and the garbage can. Asia Pacific Viewpoint 44 (2): 89-107.

-.2007. At the end of the world: Holding on to health workers in Niue. Asian and Pacific Migration Journal 16 (2): 179-98.

Connell, J. and R. Brown. 2005. Remittances in the Pacific: An overview. Manila: Asian Development Bank.

Connell, J. and D. Conway. 2000. Migration and remittances in island microstates: A comparative perspective on the South Pacific and the Caribbean. International Journal of Urban and Regional Research 24: 52-78.

Conway, J. 2006. Tuvalu 2006 economic report: From plan to action (final draft) prepared for Ministry of Finance, Economic Planning and Industries and the Asian Development Bank. 
Crang, P., C. Dwyer, and P. Jackson. 2003. Transnationalism and the spaces of commodity culture. Progress in Human Geography 27 (4): 438-56.

Duany, J. 2002. Mobile livelihoods: The sociocultural practices of circular migrants between Puerto Rico and the United States. International Migration Review 36 (2): 355-88.

Gibson-Graham, J. K. 2005. Surplus possibilities: Postdevelopment and community economies. Singapore Journal of Tropical Geography, 26 (1): $4-26$.

Gilroy, P. 1993. The Black Atlantic-Modernity and Double Consciousness. Cambridge, Massachusetts: Harvard University Press.

Glick Schiller, N., L. Basch, and C. Szanton Blanc. 1995. From immigrant to transmigrant: Theorizing transnational migration. Anthropology Quarterly 68 (1): 121-40.

Hau'ofa, E. 1993. Our sea of islands. In A new Oceania: Rediscovering our sea of islands, ed. E. Waddell, V. Naidu and E. Hau'ofa, 2-16. Suva: University of the South Pacific.

Henry, L., G. Mohan and H. Yancopulos. 2004. Networks as transnational agents of development. Third World Quarterly 25 (5): 839-55.

Jackson, P., P. Crang, and C. Dwyer. 2004. Introduction: The spaces of transnationality. In Transnational Spaces, ed. P. Jackson, P. Crang, and C. Dwyer, 1-13. Routledge: London, New York.

Koteka-Wright, E. 2006. Te uu no te akau roa': Migration and the Cook Islands. MA thesis, Massey University, NZ.

Lane, A. D. 1999. Flags of convenience: Is it time to redress the balance? Maritime Review 31-5.

Lee, H. 2007. Transforming transnationalism: Second generation Tongans overseas. Asian and Pacific Migration Journal 16 (2): 157-78.

Leontis, A. 1997. Mediterranean topographies before balkanization: On Greek diaspora, emporion, and revolution. Diaspora 6 (2): 179-94.

Levitt, P., J. DeWind, and S. Vertovec. 2003. International perspectives on transnational migration: An introduction. The International Migration Review 37 (3): 565-75.

Marsters, E., N. Lewis, and W. Friesen. 2006. Pacific flows: The fluidity of remittances in the Cook Islands. Asia Pacific Viewpoint 47 (1): 31-44.

New Zealand Immigration 2007. Pacific Access Category. http://www.immigration.govt.nz/migrant/stream/live/pacificaccess/ (accessed 19 November 2007). 
Portes, A. 2003. Conclusion: Theoretical convergences and empirical evidence in the study of immigrant transnationalism. The International Migration Review 37 (3): 874-92.

Portes, A., L. E. Guarnizo, and P. Landolt. 1999. The study of transnationalism: Pitfalls and promise of an emergent research field. Ethnic and Racial Studies 22 (2): 217-37.

Pries, L. 1998. "Transmigranten" als ein Typ von Arbeitswanderern in pluri-lokalen sozialen Räumen. Soziale Welt 49: 135-50.

Sampson, H. 2003. Transnational drifters or hyperspace dwellers: An explorative of the lives of Filipino seafarers aboard and ashore. Ethnic and Racial Studies 26 (2): 253-77.

Steinberg, Ph. E. 1999. The maritime mystique: sustainable development, capital mobility, and nostalgia in the world ocean. Environment and Planning D: Society and Space 17: 403-26.

Vertovec, S. 2001. Transnationalism and identity. Journal of Ethnic and Migration Studies 27 (4): 573-82.

- 2003. Migration and other modes of transnationalism: Towards conceptual cross-fertilization. The International Migration Review 37 (3): 641-65.

Voigt-Graf, C. 2007a. Special Issue on 'The Pacific Islanders and the Rim: Linked by Migration'. Asia Pacific Migration Journal 16 (2).

- 2007b. Pacific Islanders and the Rim: Linked by migration. Asian and Pacific Migration Journal 16 (2): 143-56.

Wimmer, A. and N. Glick Schiller. 2003. Methodological nationalism, the social sciences, and the study of migration: An essay in historical epistemology. The International Migration Review 37 (3): 576-610.

World Bank. 2006. Expanding job opportunities for Pacific Islanders through labour mobility at home and away. The World Bank: East Asia and Pacific Region, Poverty and Economic Policy Unit.

Wu, B. 2002. Seafarers: The first global villagers? The Sea 157: 4.

Yeoh, B., K. D. Willis, and S. M. A. Khader Fakhri. 2003. Transnational edges - introduction: Transnationalism and its edges. Ethnic and Racial Studies 26 (2): 207-17.

Young, R. G. 1998. Pathways as metaphors of movement: A study of place, mobility and embodiment in Fiji. PhD thesis, Victoria University, NZ. 


\section{ENDNOTES}

${ }^{1}$ Some team members of the Seafarers International Research Centre (SIRC; for more information see http://www.sirc.cf.ac.uk/) in Cardiff have suggested that seafarers are pioneers of global citizens or can be regarded as global villagers (eg. Lane 1999, Wu 2002);

2 This was originally the Marine Training School (MTS)

3 Note that I-Kiribati means coming from or belonging to Kiribati

4 The SPMS office explained in 2006, that currently six companies are involved.

5 It was only in the 1980s that Germany introduced its official foreign ship register

6 The term de-national refers to 'deterritorialised' spaces and/or actions; in other words those that operate 'beyond' national boundaries (see also Sampson 2003: 260).

7 Training facilities for both domestic and international merchant seafarers are available throughout the Pacific. Fiji and PNG offer excellent quality training for international ratings and officers, Vanuatu, Samoa, Tonga, and the Solomon Islands also are involved in training especially for international ratings and domestic officers. The largest numbers, however are being provided by Kiribati, followed by Tuvalu and Fiji.

8 In Kiribati, 40 per cent of the population in 2000 was under 14 years old (Asian Development Bank 2002a:139).

${ }^{9}$ Currently 44 per cent of the Tuvaluan population lives on Funafuti (Asian Development Bank 2002b:2).

10 This last aspect has been described in detail in Borovnik 2005.

11 Agencies try to have smaller or larger groups of I-Kiribati on one vessel, and the same applies to Tuvaluans, in order to help with emotional hardship that men experience. This is, however, not always possible.

12 This is the order in which this man mentioned those items.

13 Traditional men's clothes 